\title{
Holmes' Tremor due to Hemi-cerebellar Encephalomalacia and Improvement with Valproic Acid Therapy
}

\author{
Hemiserebellar Ensefalomalaziye Bağlı Gelişen Holmes Tremoru ve Valproik Asit \\ Tedavisi ile Düzelme
}

Keywords: Holmes' tremor, cerebellar lesion, valproate, pathophysiology

Anahtar Kelimeler: Holmes tremor, serebellar lezyon, valproat, patofizyoloji

\section{Dear Editor,}

A-70-year-old female was admitted to our clinic due to rightsided unilateral tremor that was prominent in the upper extremity, which had significantly progressed over the last five years such that she had difficulty in performing fine motor skills and many self-care activities. Upon history-taking, it was learnt that the tremor had started with a short interval (approximately one month) following a hemi-cerebellar resection surgery for meningioma, 20 years ago. The patient and her relatives stated a continuous progression of tremor over the last 20 years. On neurologic examination, rightsided unilateral rest tremor of the upper extremity was apparent that was more prominent during maintenance of posture and intention, which was compatible with Holmes' tremor (Video 1). Cerebellar examination showed right-sided dysdiadochokinesia and truncal ataxia; other neurologic examinations including motor and sensory functions were within normal limits. Cranial magnetic resonance imaging showed encephalomalacia in the right cerebellum (Figure 1). Levodopa/benserazide 3x100/25 mg and pramipexole 3 mg were tried separately, which failed to provide any improvement. However, valproic acid 2x500 mg treatment provided a moderate improvement in the severity of all subtypes of the tremor (resting, postural, and intention) (Video 2).

The mechanisms underlying Holmes' tremor have been tried to be explained in the setting of disturbances of both the nigrostriatal dopaminergic pathway and cerebello-thalamic systems (1). However, the pathophysiologic basis of this phenomenon has not

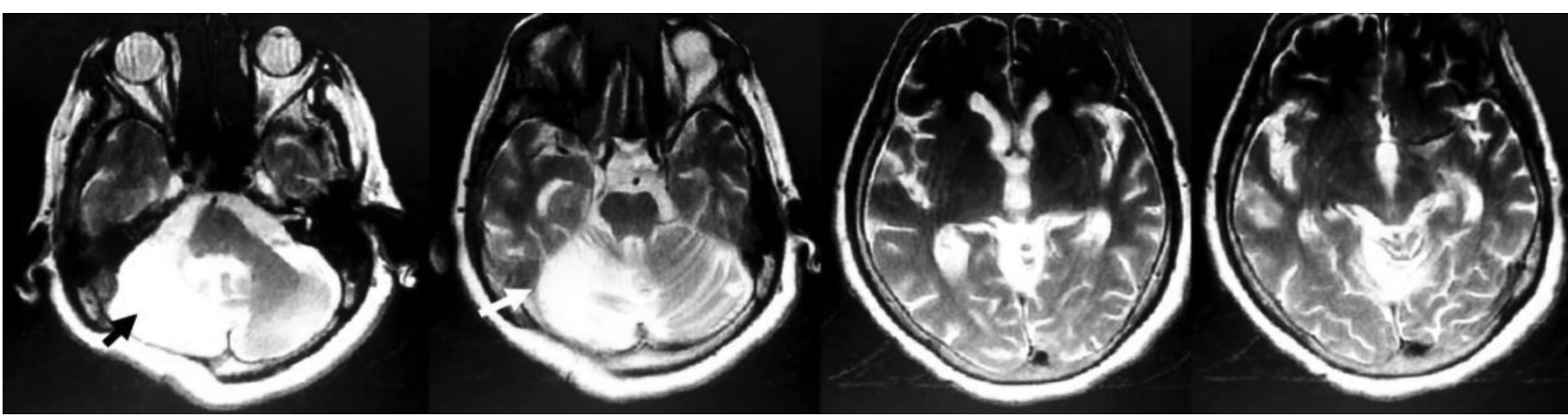

Figure 1. Cranial magnetic resonance imaging showing encephalomalacia in the right cerebellum (arrows)

Address for Correspondence/Yazışma Adresi: Halil Önder MD, Yozgat City Hospital, Clinic of Neurology, Yozgat, Turkey Phone: +90 5376836864 E-mail: halilnder@yahoo.com ORCID ID: orcid.org/0000-0002-1823-2278

Received/Geliş Tarihi: 12.06.2018 Accepted/Kabul Tarihi: 13.12 .2018

${ }^{\circ}$ Copyright 2019 by Turkish Neurological Society

Turkish Journal of Neurology published by Galenos Publishing House. 
Video 1. Neurologic examination at admission showing tremor, which was apparent during rest, posture, and intention, compatible with Holmes tremor.

http://www.tjn.org.tr/jvi.aspx?pdir=tjn\&plng=eng\&un=TJN-84666\&look4=

Video 2. Neurologic examination on valproic acid $1000 \mathrm{mg} /$ day therapy, showing a mild-moderate amelioration in tremor severity.

\section{http://www.tjn.org.tr/jvi.aspx?pdir=tjn\&plng=eng\&un=TJN-84666\&look4=}

yet been fully understood. In our patient, the encephalomalacia did not include dopaminergic regions (nigrostriatal). Remarkably, levodopa and dopaminergic agonist therapies failed to provide any amelioration, suggesting malfunction of a mechanism other than dopaminergic networks. Levodopa is a forefront treatment for the treatment of Holmes's tremor. On the other hand, pathophysiologic heterogeneity in Holmes' tremor and varying responses to levodopa individually have constituted crucial discussions in recent reports (2). Remarkably, in the interesting report by Gajos et al. (2), dopaminergic deficit revealed with dopamine transporter SCAN single-photon emission computed tomography was suggested to be a potential indicator of levodopa responsiveness in Holmes tremor. Nevertheless, to the best of my knowledge, a possible relationship between the responsible lesion site of Holmes' tremor and varying therapy responses has not been investigated in a previous report. In my opinion, the lesion site may potentially be a criterion to be kept in mind while choosing the most appropriate therapy regimens. For instance, the lesion site of the cerebellum may be a predictor of levodopa unresponsiveness. In accordance with this thought, in another unique report, Brittain et al. (3) illustrated a patient with Holmes' tremor due to hemi-cerebellar lesion in whom levodopa therapy provided no improvement, as in our patient. deep brain stimulation therapy was reported to result in a significant recovery of tremor in this patient, prominently in the resting and postural tremors (3).

Remarkably, Holmes' tremor has been suggested to develop due to an absence of unilateral cerebellar input in patients with cerebellar lesions. Besides, valproic acid was shown to act via inhibition of glycogen synthase- 3 phosphorylation of microtubuleassociated protein 1B in cerebellar granule cells (4). It can be hypothesized that the efficiency of valproate in our patient might have occurred via a mechanism leading to amelioration of some disturbed cerebellar functions. However, based on a unique case and limited literature data, these considerations can only be hypothesized. Future reports of large case series addressing varying treatment responses according to the lesion locations are warranted to clarify these hypotheses. The results of these studies may add substantial contributions to our understanding of the pathophysiology of Holmes' tremor.

\section{Ethics}

Informed Consent: Consent form was filled out by all participants.

Peer-review: Internally peer-reviewed.

Financial Disclosure: The author declared that this study received no financial support.

\section{References}

1. Deuschl G, Bain P, Brin M. Consensus statement of the Movement Disorder Society on Tremor. Ad Hoc Scientific Committee. Mov Disord 1998;(13 Suppl 3):2-23.

2. Gajos A, Bogucki A, Schinwelski M, et al. The clinical and neuroimaging studies in Holmes tremor. Acta Neurol Scand 2010;122:360-366.

3. Brittain JS, Jenkinson N, Holland P, et al. Development of Holmes' tremor following hemi-cerebellar infarction. Mov Disord 2011;26:1957-1959.

4. Hall AC, Brennan A, Goold RG, et al. Valproate regulates GSK-3-mediated axonal remodeling and synapsin I clustering in developing neurons. Mol Cell Neurosci 2002;20:257-270. 